\title{
Annual, seasonal and spatial abundance of the seabob shrimp Xiphopenaeus kroyeri (Decapoda, Penaeidae) off the Southeastern coast of Brazil
}

\author{
GISELE S. HECKLER ${ }^{1}$, MATEUS LOPES ${ }^{2}$, SABRINA M. SIMÕES ${ }^{3}$, \\ ROBERTO M. SHIMIZU ${ }^{1}$ and ROGERIO C. DA COSTA ${ }^{3}$ \\ ${ }^{1}$ Departamento de Ecologia, Instituto de Biociências, USP, \\ Rua do Matão, Travessa 14, n. 321, Cidade Universitária, 05508-090 São Paulo, SP, Brasil \\ ${ }^{2}$ Departamento de Biologia, FFCLRP/ USP, Av. Bandeirantes, 3900, 14040-901 Ribeirão Preto, SP, Brasil \\ ${ }^{3}$ Departamento de Ciências Biológicas, Faculdade de Ciências/ UNESP, \\ Av. Eng ${ }^{\circ}$ Luis Edmundo Carrijo Coube, 14-01, Vargem Limpa, 17033-360 Bauru, SP, Brasil
}

Manuscript received on May 29, 2013; accepted for publication on November 4, 2013

\begin{abstract}
We investigated the influence of environmental factors in spatial and temporal distribution of the seabob shrimp Xiphopenaeus kroyeri in Santos Bay and São Vicente Estuary, state of São Paulo, Brazil. Monthly samples were obtained, from May 2008 through April 2010, from four locations in the estuary and four in the bay. No individual was collected in the estuary and this was attributed to the low salinity means recorded in this environment. We collected 109,153 individuals in the bay and there was no difference in abundance between the two years comprised by the study period. The similarity in spatial distribution can be related to sediment grain size that in all sampling locations showed great amount of very fine sand. The largest amount of reproductive females was obtained in early 2010, when temperature was high, and this could have increased the juvenile recruitment in April 2010. According to our results, the distribution of $X$. kroyeri in the study area is influenced by temperature, which is related to reproduction, and salinity, limiting the entrance of individuals in the estuarine region.
\end{abstract}

Key words: distribution, environmental factors, estuary, Santos Bay.

\section{INTRODUCTION}

The seabob shrimp Xiphopenaeus kroyeri is widely distributed in the Western Atlantic, from Virginia (USA) $\left(75^{\circ} 43^{\prime} \mathrm{W} ; 36^{\circ} 54^{\prime} \mathrm{N}\right)$ to Southern Brazil (32 $\left.39^{\prime} \mathrm{S} ; 52^{\circ} 20^{\prime} \mathrm{W}\right)$ (Costa et al. 2000). Occurring in high abundances in shallow waters $(<30 \mathrm{~m})$ and attaining suitable body size for commercial exploitation (Castro et al. 2005), X. kroyeri is an important species for fishery.

Correspondence to Rogerio Caetano da Costa

E-mail: rccosta@fc.unesp.br
In Brazil, it occurs virtually throughout the coast but intense fishery is restricted to the states of Maranhão and Bahia (Northeast), São Paulo (Southeast) and Santa Catarina (South) (Ibama 2007). The impact of this intense exploitation on the $X$. kroyeri stocks became evident in the Southern and Southeastern coast during the decades of 1980 and 1990 when annual landings decreased alarmingly from 8000 to $1000 \mathrm{t}$ (D'Incao et al. 2002). Although annual landings recovered from 640 to $3180 \mathrm{t}$, from 2000 through 
2012 in the state of São Paulo (Instituto de Pesca 2013), the values remain distant from those observed previously.

The studied region plays an important role with regards to fishery, especially for X. kroyeri. Studies on the seabob shrimp in the region comprise a survey of macrocrustaceans (Reigada et al. 2006) and an assessment of the fisheries (Graça-Lopes et al. 2007). However, there is no study about spatial and temporal distribution of this species in different demographic categories.

Previous studies on $X$. kroyeri populations of the northern coast of the state of São Paulo concluded that high temperature, salinity and very fine sand influenced the distribution of this species (Fransozo et al. 2002, Costa et al. 2007, Castilho et al. 2008b). A relevant complementation for these findings would be a more detailed analysis of these populations involving demographic categories, since marine shrimps establish in areas with different environmental characteristics, according to their life stage (Dall et al. 1990).

Another aspect of $X$. kroyeri biology that needs additional investigation is whether the juveniles use estuaries as habitats or not. According to Dall et al. (1990), López and García (2001) and Marques (2009) this species spends part of its life cycle in estuarine environment. However, Costa et al. (2011) did not collect any individual of $X$. kroyeri in the Indaiá estuary (northern coast of the state of São Paulo), probably because of the reduced size of the environment.

We analyzed the spatial and temporal abundance of $X$. kroyeri and the possible influence of abiotic factors (bottom water temperature and salinity, organic matter content, and sediment texture), considering the population as a whole and in its demographic categories. These possible relations are vital for a better understanding of the species biology concerning the location and time of reproduction and recruitment. This is in turn valuable information for improvement of stock management.
Data were obtained in a region with a large estuary to check if the dimension of the environment interferes in its use by this shrimp. It is important to verify the presence or absence of this species in a larger estuary since the local legal off-season is based in the area of the recruitment of the species, beyond its period.

\section{MATERIALS AND METHODS}

The study area is located at the central coast of the

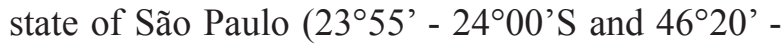
$\left.46^{\circ} 25^{\prime} \mathrm{W}\right)$, that includes Santos Bay, and Santos and São Vicente Estuaries. The area is included in the legal off-season for the shrimp that occurs from March through May in the South and Southeastern coast of Brazil.

Monthly samples were taken between May 2008 and April 2010 at four locations in the São Vicente Estuary and four in the Santos Bay. The locations in the estuary were defined along the salinity gradient, and those in the bay were defined according to a depth gradient from 8 (location 5) to $14 \mathrm{~m}$ (location 7). Location 8 was marked on an area that was protected from wave action (Fig. 1) (Table I).

Shrimp was captured with the aid of a fishing boat equipped with a $10 \mathrm{~m}$ long otter trawl net with $8 \mathrm{~m}$ mouth aperture. Mesh size was $20 \mathrm{~mm}$ (18 mm in the cod end). Hauls lasted for 30 minutes at the bay and 10 minutes at the estuary, both at average speed of 2 knots. Hauling time was shorter at the estuary due to the muddy sediment and the occurrence of large amounts of plant debris, which made a 30-minutes-haul impracticable.

In each trawl, we collected a bottom water sample using a Van Dorn bottle and measured salinity with an optic refractometer ( 0.1 scale), and temperature with a mercury thermometer $\left(0.1^{\circ} \mathrm{C}\right.$ scale). A sediment sample was also collected with a Van Veen grab with $0.06 \mathrm{~m}^{2}$ sampling area. From the obtained samples we determined sediment texture by sieving and organic matter content by incineration. The procedures used for sediment 

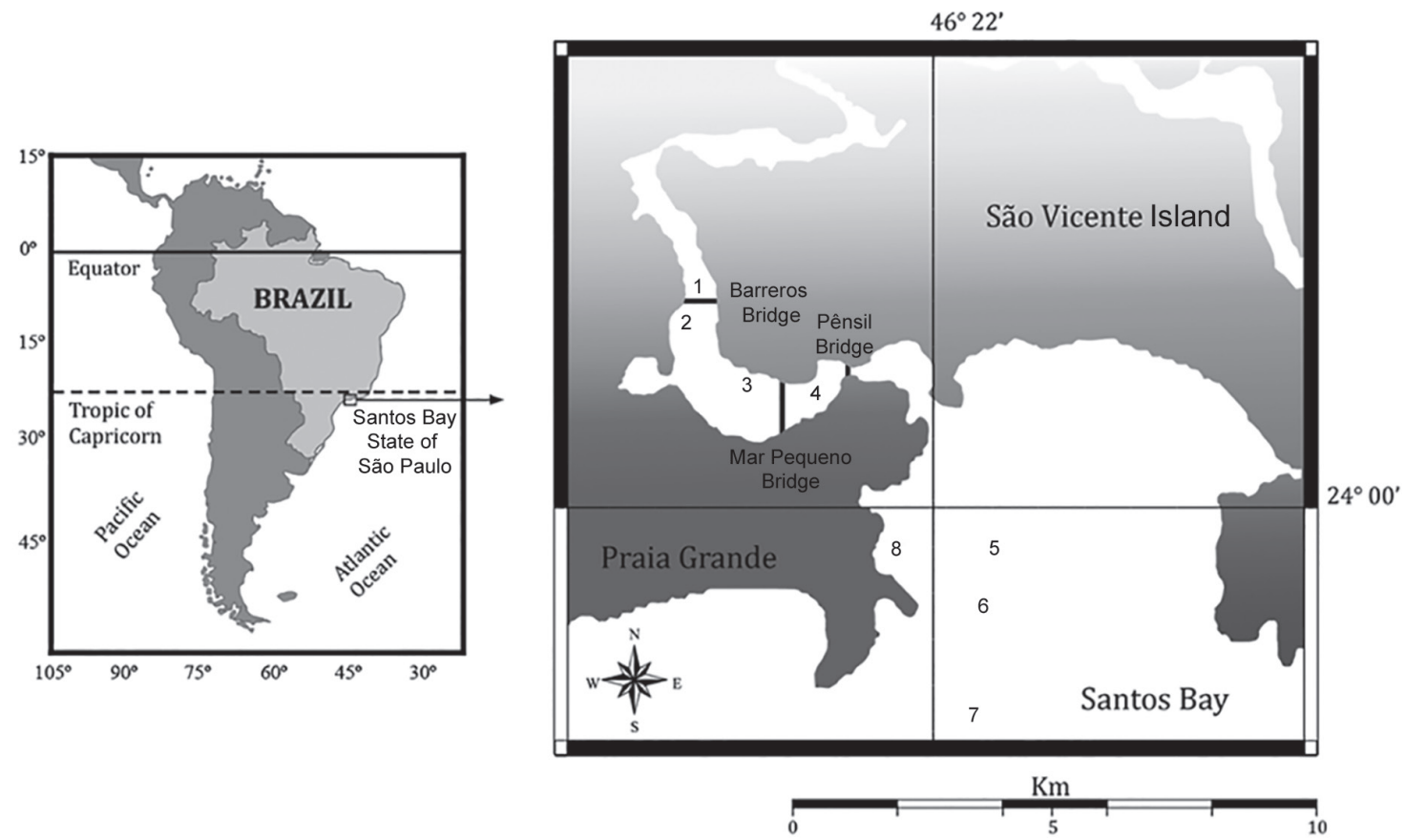

Fig. 1 - Map of study area indicating locations 1-4 in the São Vicente Estuary, and 5-8 in the Santos Bay, São Paulo, Brazil.

TABLE I

Mean depth (m) and standard deviation (SD) of each sample location in the São Vicente Estuary (1-4) and the Santos Bay (5-8), São Paulo, Brazil.

\begin{tabular}{ccccccccc}
\hline Location & 1 & 2 & 3 & 4 & 5 & 6 & 7 & 8 \\
\hline Mean & 3.3 & 4.9 & 4.5 & 4.1 & 8.3 & 10.5 & 14.1 & 6.9 \\
\pm & \pm & \pm & \pm & \pm & \pm & \pm & \pm & \pm \\
$\mathrm{SD}(\mathrm{m})$ & 0.55 & 0.66 & 0.71 & 0.32 & 0.41 & 0.83 & 1.73 & 0.48 \\
\hline
\end{tabular}

texture and organic matter content analysis followed those reported by Costa et al. (2007). Mean particle size was expressed in phi numbers $\left(-\log _{2}\right.$ of diameter in millimeters).

The collected specimens were identified using a specific key (Costa et al. 2003). From each sample we obtained the total weight ( $\mathrm{g}$ ) and a $400 \mathrm{~g}$ subsample on which all individuals were counted. The abundance in each category and the total of all categories were obtained based on individuals number and weight of the subsample, and on total weight of the correspondent sample.

The reproductive condition of each female was determined by characteristics of thelycum (seminal receptacles) and macroscopic observation of the reproductive system (adapted from Dumont and D'Incao 2004). When thelycum was not completely closed, females were considered immature or juvenile (IM). Adult females (closed thelycum) were classified in non-reproductive when ovaries were in the rudimentary stage (RU: light color and small size), and reproductive when gonads were mature (MA: dark color and large size, indicating that ovaries were full of oocytes). Males were considered to be juveniles when petasma was not linked and adults when it was linked (Castro et al. 2005).

The temporal variation in abundance of $X$. kroyeri was analyzed in two time scales: between 12-month periods (May 2008-April 2009 vs. May 2009-April 2010) and between months in the total study period. The Kolmogorov-Smirnov (normality) and Levene (homocedasticity) tests were employed to verify the parametricity of data. The 12-month periods were compared with paired-samples t-test (data were paired by sampling location-month combination). Comparisons among months were performed with random block analysis of variance (ANOVA) in which sampling locations defined the 
blocks. When results of this test were significant we performed multiple comparisons, applying the paired-sample t-test with the Bonferroni correction on the significance level $\left(\alpha^{\prime}=\alpha /\right.$ number of comparisons; Sokal and Rohlf 1995) to detect differences among pairs of sample locations or months. This latter method was also employed when verifying spatial variation in abundance (comparisons between sampling locations). Tests were performed with the aid of the Statistica 7.0 (Statsoft, Inc) and Past 2.15 (Hammer et al. 2001) softwares.

Possible associations between population abundance (as a whole and in its demographic categories) with water and sediment variables were verified with multiple linear regression, performed with Microsoft Excel program. All statistical procedures followed Zar (1996) except where noted.

\section{RESULTS}

Bottom water salinity in locations in the Santos Bay showed small temporal variation, ranging from 35.0 to 39.5 (mean $=36.7 \pm 1.2$ ), except from May through August 2008, and from March through April 2010, when values were comparatively lower (Fig. 2). Variability among sample locations was small (Fig. 3). In the estuary, salinity values were lower and more variable (Fig. 2 and 3). From May 2008 through October 2009, the variation pattern observed in the estuary was similar to those in the bay (Fig. 2). Among sample locations, as expected, we observed an increasing salinity value towards the open sea.

Bottom water temperature in the bay varied seasonally with higher values $\left(>24^{\circ} \mathrm{C}\right)$ occurring from midsummer through autumn (January-May 2009; January-April 2010). Values decreased in winter, increasing again in spring (September 2008; November 2009). In November and December 2008 temperature decreased markedly just before the warmer period of the year (Fig. 2). A similar pattern of temporal variation occurred in the estuary, although mean temperature values were higher than those of the bay in the warmest months (from October 2008 through March 2009, and from November 2009 through February 2010). Between sample locations, temperature variation was small both in the bay and in the estuary (Fig. 3).

Very fine sand $(3<$ phi $\leq 4)$ associated to low organic matter content (1.8 - $2.9 \%)$ predominated in sediment of all sampling locations in the bay. In the estuary fine sand constituted the sediment of location 4 and very fine sand predominated in the others. The largest proportions of silt and clay, and the highest organic matter content were recorded in locations 2 and 3 (Table II).
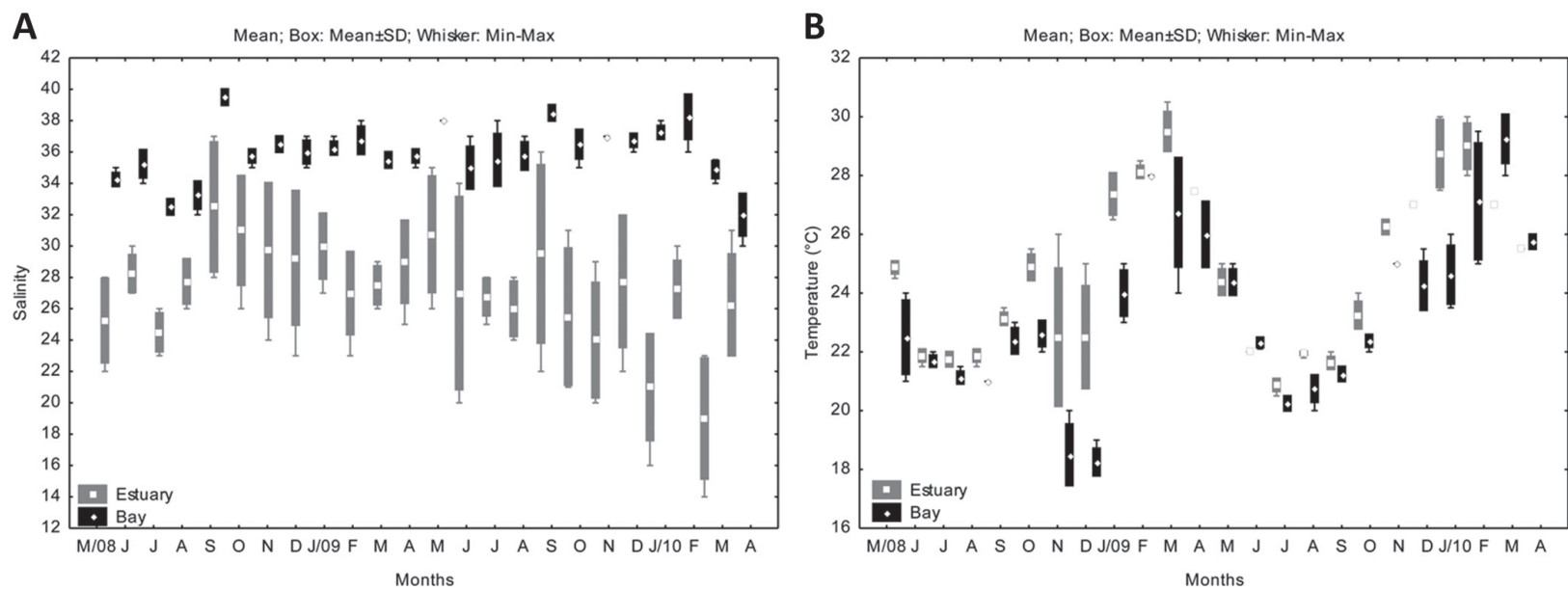

Fig. 2 - The mean, standard deviation, maximum and minimum values of $(\mathbf{A})$ salinity and $(\mathbf{B})$ temperature $\left({ }^{\circ} \mathrm{C}\right)$ recorded from May 2008 through April 2010 in the sample locations in the Santos Bay and the São Vicente Estuary. 
A

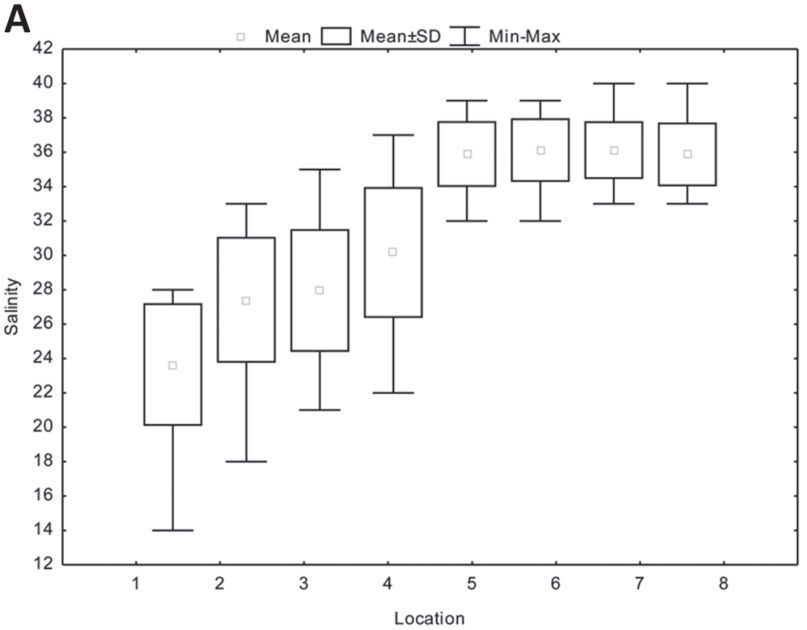

B

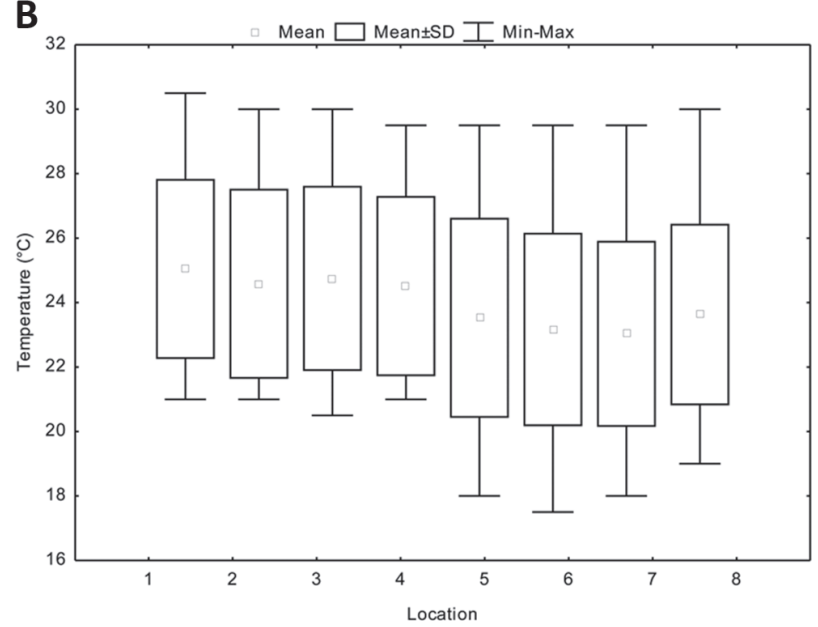

Fig. 3 - The mean, standard deviation, maximum and minimum values of (A) salinity and (B) temperature $\left({ }^{\circ} \mathrm{C}\right)$ in the sample locations in the São Vicente Estuary (1-4) and in the Santos Bay (5-8), São Paulo, Brazil, from May 2008 through April 2010.

TABLE II

The mean values of sediment texture (Phi), percentage of silt and clay, and organic matter content (O.M.) for each sample location in the São Vicente Estuary (1-4) and in the Santos Bay (5-8) from May 2008 through April 2010.

\begin{tabular}{cccc}
\hline Location & Phi & \% silt+clay & \% O.M. \\
\hline 1 & 3.14 & 8.32 & 2.59 \\
2 & 3.87 & 24.46 & 5.65 \\
3 & 3.85 & 25.12 & 5.40 \\
4 & 2.70 & 3.70 & 2.19 \\
5 & 3.55 & 5.40 & 1.84 \\
6 & 3.61 & 8.98 & 2.22 \\
7 & 3.75 & 17.16 & 2.94 \\
8 & 3.54 & 3.51 & 2.27 \\
\hline
\end{tabular}

No specimen of $X$. kroyeri was captured in the estuary. In the bay, individuals were collected during the study period totaling 109,153 . No significant difference in abundance was detected between the two 12-month periods (Table III).

Total abundance differed between months in both 2008-2009 $(F=5.18 ; p=0.0001)$ and 2009-2010 $(F=5.89 ; p=0.00003)$ periods. Significant results were also obtained for all demographic categories: juveniles $(\mathrm{F}=2.35 ; \mathrm{p}=0.02 ;$ and $\mathrm{F}=25.38 ; \mathrm{p}<$ $0.0001)$, adult males $(\mathrm{F}=8.86 ; \mathrm{p}<0.0001$; and $\mathrm{F}=$ $2.98 ; \mathrm{p}=0.007)$, adult females with rudimentary ovaries $(\mathrm{F}=3.62 ; \mathrm{p}=0.001 ;$ and $\mathrm{F}=7.10 ; \mathrm{p}<$ $0.0001)$, and reproductive females $(F=5.10 ; p=$
TABLE III

Number of individuals of Xiphopenaeus kroyeri in total, juvenile, adult male, adult female with rudimentary ovaries (RU) and reproductive females (MA) collected from May 2008 through April 2009, and from May 2009 through April 2010, with t and p-values.

\begin{tabular}{ccccc}
\hline & $2008-2009$ & $2009-2010$ & t-value & p-value \\
\hline Total & 51268 & 57885 & -0.50 & 0.61 \\
Juvenile & 5146 & 8413 & -1.47 & 0.14 \\
Adult Male & 22495 & 25502 & -0.49 & 0.62 \\
RU Female & 20583 & 20672 & -0.02 & 0.98 \\
MA Female & 3044 & 3298 & -0.35 & 0.72 \\
\hline
\end{tabular}

0.001; and $\mathrm{F}=2.74 ; \mathrm{p}=0.01)$. Although multiple comparisons provided no significant results $(\mathrm{p}>\alpha$ ' $=0.0007$ ), in the 2008-2009 period the $p$-value of some comparisons involving reproductive females was close to $\alpha^{\prime}(0.002$ to 0.0007$)$ indicating that this category was less abundant in May and July in comparison to December.

In the 2009-2010 period, the total population and juveniles (when separated in demographic categories) were more abundant in April in comparison to the other months. Adult females with rudimentary ovaries were captured intensively in May 2009 and April 2010. The number of adult males and reproductive females did not differ statistically among sampling months of this period (Fig. 4). 

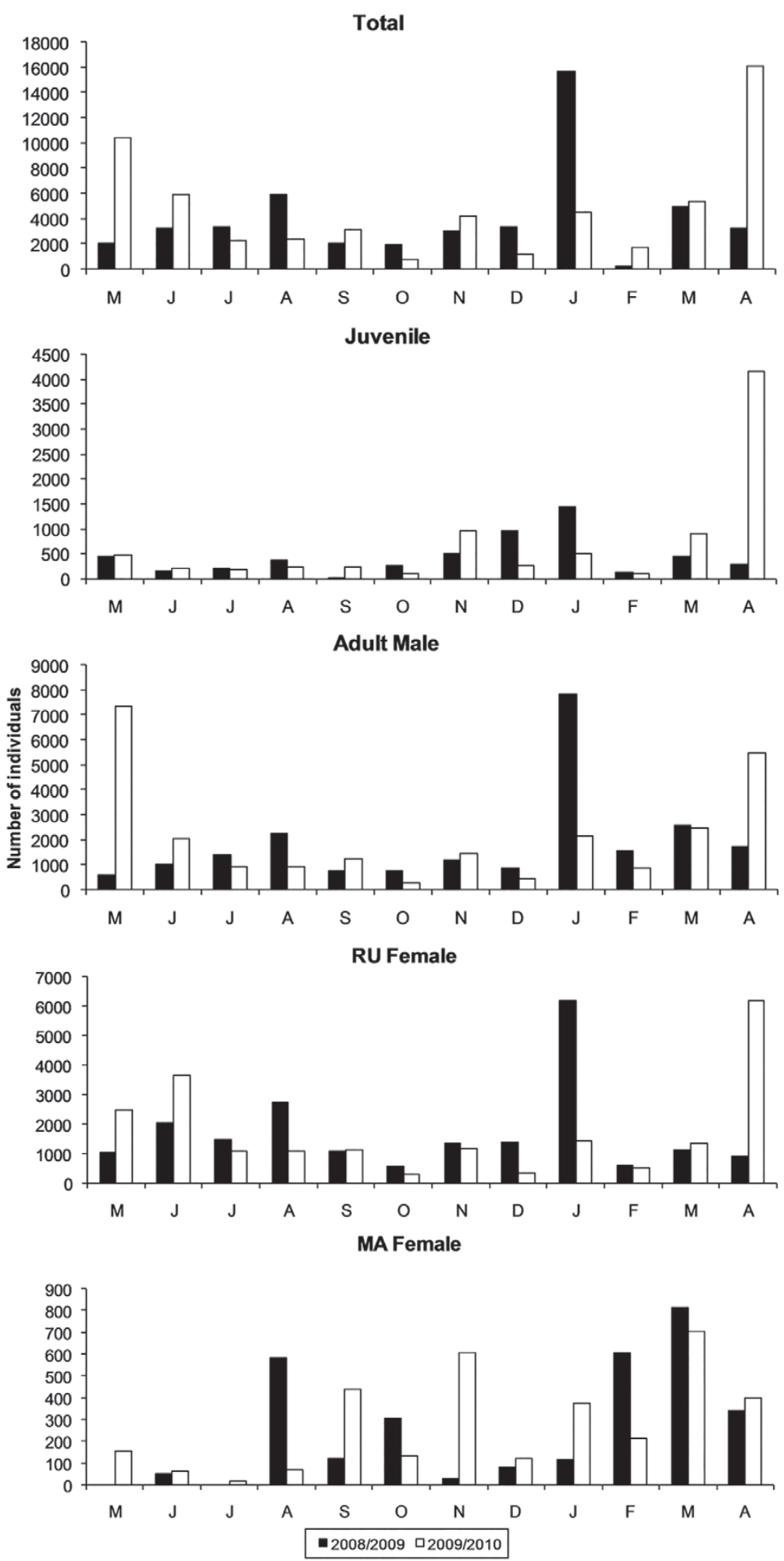

Fig. 4 - Number of individuals in total, juvenile, adult male, adult female with rudimentary ovaries (RU) and reproductive females (MA) of Xiphopenaeus kroyeri sampled in the Santos Bay from May 2008 through April 2010. Each graphic indicates a different $y$-scale to facilitate visual analysis. 
The abundance of each demographic category among sampling locations is shown in Fig. 5. The abundance of individuals among sampling locations did not differ statistically in the period of $2008-2009(\mathrm{~F}=2.12 ; \mathrm{p}=0.11)$ nor in the period of 2009-2010 $(F=0.38 ; p=0.76)$. Similar results were obtained for all demographic categories.
Multiple linear regression indicated positive relation between reproductive females and temperature $(p=0.0001)$. Juveniles were negatively related to salinity $(\mathrm{p}=0.039)$ and positively related to organic matter content $(\mathrm{p}=0.011)$. Total population and the other demographic categories did not associate significantly with abiotic factors. The

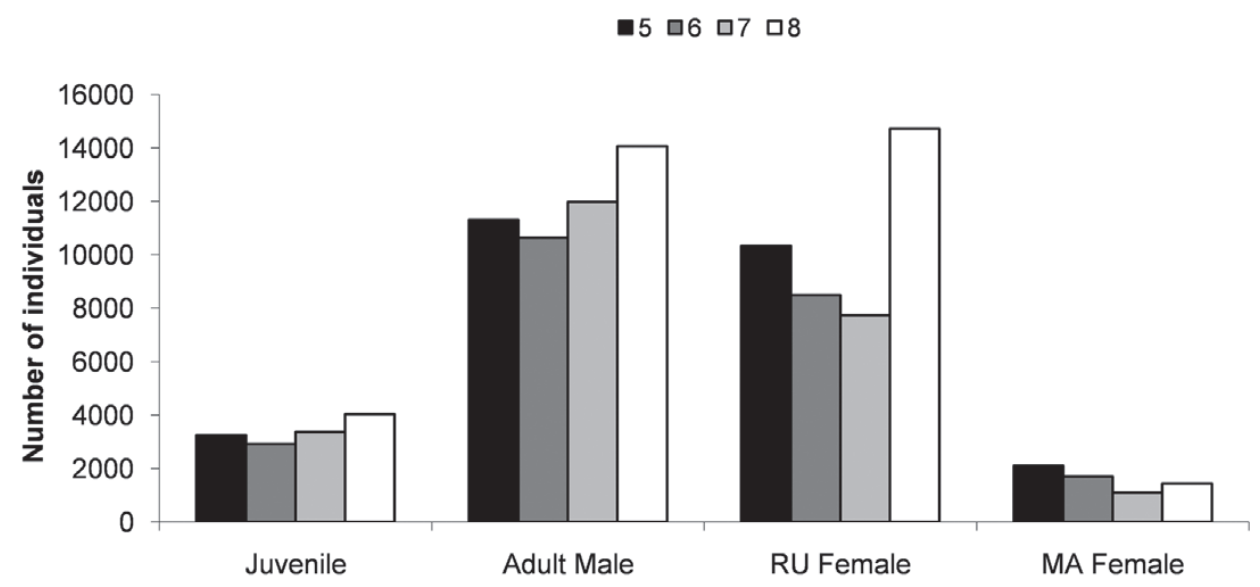

Fig. 5 - Number of individuals of Xiphopenaeus kroyeri in each demographic category sampled in locations 5 to 8 of the Santos Bay, from May 2008 through April 2010 (RU= adult females with rudimentary ovaries; $\mathrm{MA}=$ reproductive females).

result of multiple regressions can be expressed by the following equations:

Reproductive females: $A=-14.5+5.26 T$

Juveniles: $A=11.75-6.28 S+1.47 O M$

where: $A=$ abundance; $T=$ temperature; $S=$ salinity; and $O M=$ organic matter.

\section{DISCUSSION}

No individual was found in the São Vicente Estuary. Among the abiotic factors that we analyzed, salinity was probably the reason for the absence of $X$. kroyeri in this environment. This estuary has a great extension and a wide mouth, and these characteristics enable wide ranges of salinity variation due to exposure to tidal action. Although high mean salinity values were registered in the location near the bay, variability was much larger than in the locations in the bay, and values remained lower than 30 in most of the months.
Tolerance to the range of salinity can differ among populations of the same species according to their geographical origin, and according to their different phases of life (Péqueux 1995). In Colombian Caribbean and in the state of Pará, north coast of Brazil, post-larvae and juveniles of $X$. kroyeri were caught in the estuary (López and García 2001, Marques 2009). The differences in salinity tolerance can also be associated to distinct genetic characteristics in these populations. Gusmão et al. (2006) believe that the occurrence of two different species of Xiphopenaeus in Brazil is based on the high levels of molecular divergence among these species.

Studies in South and Southeast of Brazil (Branco 2005, Castro et al. 2005, Campos et al. 2009, Fernandes et al. 2011, Heckler et al. 2013) showed that the juvenile recruitment of this species occurred close to the costal line, up to $15 \mathrm{~m}$ of 
depth, as we observed in the present study. We can infer that $X$. kroyeri in the Santos and São Vicente regions, as well as in the South and Southeast coast of Brazil, completes its life cycle at the in-shore areas and is not dependent on estuarine regions, and should be in life cycle type 3, according to the life cycle classification system of Dall et al. (1990).

Although salinity was fairly constant in the bay, mean values exceeded 39 in September 2008, when the capture of juveniles was fewer than in other months. This is in accordance to the inverse relation between juvenile abundance and salinity, obtained with the multiple regression, that indicates that these individuals do not tolerate high saline concentration.

The studied region is influenced by the South Atlantic Central Water (SACW), a water mass that decreases bottom temperature and salinity throughout late spring and summer (Castro-Filho et al. 1987). During the study period, the influence of the SACW was evident in November and December 2008 when mean bottom temperatures fell below $20^{\circ} \mathrm{C}$. In the following year the effect of the water mass was negligible, since mean temperature remained around $23^{\circ} \mathrm{C}$ in the deepest sampling location.

The difference of SACW intensity between the two periods was also observed by Batista et al. (2011) who studied Pleoticus muelleri and Artemesia longinaris in the same period and area of the present study. The authors stated that these two cold water species that indicate the presence of SACW in coastal areas (Castilho et al. 2008a) were abundant in late spring of 2008 and in summer of 2009 but only a few specimens were captured one year later.

Our results showed that in the first period, from November to January, a low amount of reproductive female was sampled when compared to the second period. Laboratory researches indicated that temperature has a direct influence on peneid larval development and survival (Cockcroft and
Emmerson 1984, Kumlu et al. 2000). Considering this information in addition to the positive relation between abundance of reproductive females and temperature, we considered that the presence of high temperature in late 2009 specifically favored the increase of reproductive females, which in turn enhanced the number of juveniles in April 2010.

Since $X$. kroyeri has benthic habits, the availability of sediment types is important for their distribution (Costa et al. 2007, Castilho et al. 2008b) once it provides protection against predators and minimizes energy cost when buried (Ameeri and Cruz 1998, Simões et al. 2010). Sediment of all sampling locations of the bay showed predominance of very fine sand. This accounts for the non-significant results when the abundance between sampling locations were compared or when the relation between number of individuals and sediment texture were investigated. Sediment with this texture favors the establishment of $X$. kroyeri because it is compatible to excavation and burying abilities of this shrimp (Freire et al. 2011).

In the Santos Bay, the distribution of demographic categories did not differ among the sampling locations, and it suggests that both juveniles and adults share the same habitat, as observed by Branco (2005) for this species.

The positive relation observed between juveniles and organic matter content suggests that the importance of this variable becomes evident under homogenous sediment texture conditions. Although gammarid amphipods and other crustaceans have been described as main food items for X. kroyeri (Branco and Moritz-Jr 2001), penaeid shrimps complement their diets ingesting organic matter from the sediment (Chong and Sasekumar 1981).

Since we observed abundance peaks in December and April in the sampling period, the interruption of fishing during March through May could enable a larger capture during the period. Moreover, in April 2010 juvenile recruitment was 
higher as a result of the intense reproduction activity at the beginning of the year, which increased juvenile abundance.

According to our results, the distribution of $X$. kroyeri in the studied area was influenced by environmental factors, mainly temperature and salinity. The temperature influenced the temporal distribution of reproductive females and the salinity was probably the limiting factor for the entrance of individuals in the estuarine region. The results reinforce the view that the species does not depend on the estuarine environment to complete its life cycle.

The legal off-season established for the region seems to be adequate to protect $X$. kroyeri once all the categories, mainly juveniles and reproductive females, share the same protected area during these months.

\section{ACKNOWLEDGMENTS}

We are thankful to Dr Fernando José Zara, the LABCAM co-workers and Evandro Dias for their help during the fieldwork. We are also grateful to the Fundação de Amparo à Pesquisa do Estado de São Paulo (FAPESP) (\#04/07309-8, \#07/57316-9, \#08/53999-7, \#08/54991-0, \#09/54672-4, \#10/501888); and the Conselho Nacional de Desenvolvimento Científico e Tecnológico (CNPq - Edital Universal) (\#479541/2007-8) for providing financial support. All sampling in this study complied with the current applicable state and federal laws in Brazil (SISBIO/ IBAMA number 23012-1).

\section{RESUMO}

A influência dos fatores ambientais na distribuição espacial e temporal do camarão sete-barbas Xiphopenaeus kroyeri foi investigada na Baía de Santos e Estuário de São Vicente, Estado de São Paulo, Brasil. As amostras foram obtidas mensalmente, de maio de 2008 a abril de 2010, em quatro locais do estuário e quatro da baía. Nenhum indivíduo foi coletado no estuário e isto foi atribuído à baixa salinidade média registrada neste ambiente. Foram coletados 109.153 indivíduos na baía e não houve diferença na abundância entre os anos de estudo. A semelhança na distribuição espacial pode estar relacionada à composição do sedimento que em todos os locais de amostragem teve predomínio de areia muito fina. A maior quantidade de fêmeas reprodutivas foi obtida no início de 2010, quando a temperatura estava alta, e resultou em um pico de recrutamento juvenil em abril de 2010. De acordo com nossos resultados, a distribuição de $X$. kroyeri na área de estudo é influenciada pela temperatura, relacionada à reprodução, e à salinidade, que limita a entrada dos indivíduos no estuário.

Palavras-chave: distribuição, fatores ambientais, estuário, Baía de Santos.

\section{REFERENCES}

AMEERI AA AND CRUZ EM. 1998. Effect of sand substrate on growth and survival of Penaeus semisulcatus de Haan juveniles. J Aqua Trop 13: 239-244.

Batista AC, Simões SM, Lopes M AND Costa RC. 2011. Ecological distribution of the shrimp Pleoticus muelleri (Bate, 1888) and Artemesia longinaris Bate, 1888 (Decapoda, Penaeoidea) in the southeastern Brazilian littoral. Nauplius 19: 135-143.

BRANCO JO. 2005. Biologia e pesca do camarão sete-barbas Xiphopenaeus kroyeri (Heller) (Crustacea, Penaeidae), na Armação do Itapocoroy, Penha, Santa Catarina, Brasil. Rev Bras Zool 22: 1050-1062.

BRANCO JO AND MORITZ-JR HC. 2001. Alimentação natural do camarão sete-barbas, Xiphopenaeus kroyeri (Heller) (Crustacea, Decapoda) na Armação do Itapocoroy, Penha, Santa Catarina. Rev Bras Zool 18: 53-61.

CAMPos BR, DUMONT LFC, D'INCAO F AND BRANCO JO. 2009. Ovarian development and length at first maturity of the sea-bob-shrimp Xiphopenaeus kroyeri (Heller) based on histological analysis. Nauplius 17: 9-12.

Castilho AL, Costa RC, Fransozo A and NegreirosFRANSOZO ML. 2008a. Reproduction and recruitment of the South American red shrimp, Pleoticus muelleri (Crustacea: Solenoceridae), from the southeastern coast of Brazil. Mar Biol Res 4: 361-368.

CAstilho AL, Pie MR, Fransozo A, Pinheiro AP AND Costa RC. 2008b. The relationship between environmental variation and species abundance in shrimp community (Crustacea: Decapoda: Penaeoidea) in south-eastern Brazil. J Mar Biol Assoc UK 88: 119-123.

Castro RH, Costa RC, Fransozo A and Mantelatto FLM. 2005. Population structure of the seabob shrimp Xiphopenaeus kroyeri (Heller, 1862) (Crustacea, Penaeoidea) in the littoral of São Paulo, Brazil. Sci Mar 69: 105-112. 
Castro-Filho BM, Miranda LB AND MyaO SY. 1987. Condições hidrográficas na plataforma continental ao largo de Ubatuba: variações sazonais e em média escala. Bol Inst Oceanogr 35: 135-151.

ChOng VC AND SASEKUMAR A. 1981. Food and feed habits of the white prawn Penaeus merguiensis. Mar Ecol Prog Ser 5: 185-191.

COCKCROFT AC AND EMMERSON WD. 1984. The effect of temperature on the growth, development and survival of Macropetasma africanus (Balss) (Penaeoidea: Penaeidae) larvae reared in the laboratory. J Exp Mar Biol Ecol 84: 203-210.

Costa RC, Fransozo A, Freire FAM and Castilho AL. 2007. Abundance and ecological distribution of the "setebarbas" shrimp Xiphopenaeus kroyeri (Heller, 1862) (Decapoda: Penaeoidea) in three bays of the Ubatuba region, Southeastern, Brazil. Gulf Caribb Res 19: 33-41.

Costa RC, Fransozo A, MANTElatto FLM AND CASTRO RH. 2000. Occurrence of shrimp species (Natantia: Penaeidea: Caridea) in Ubatuba Bay, Ubatuba, SP, Brazil. Proc Biol Soc Wash 113: 776-781.

Costa RC, Fransozo A, MElo GAS AND Freire FAM. 2003. An illustrated key for Dendrobranchiata shrimps from the northern coast of São Paulo state, Brazil. Biota Neotrop 3: $1-12$

Costa RC, Heckler GS, Simões SM, Lopes M And CAStilho AL. 2011. Seasonal variation and environmental influences on abundance of juveniles of the seabob shrimp Xiphopenaeus kroyeri (Heller, 1862) in southeastern Brazil. In: Monograph series "Atti di Convegni" of the Ninth Colloquium Crustacea Mediterranea, PESSANI D, TIRELLI T AND FROGLIA C (Eds), Grafica Ferrieri, p. 47-58.

Dall W, Hill BJ, Rothilsberg PC AND Staples DJ. 1990. The biology of the Penaeidae. In: BLAXTER JHS AND SOUTHWARD AJ (Eds), Advances in Marine Biology, San Diego: Academic Press, San Diego, USA, 489 p.

D'INCAO F, VALENTINI H AND RodRIGUES LF. 2002. Avaliação da pesca de camarões nas regiões Sudeste e Sul do Brasil; 1965-1999. Atlântica 24: 49-62.

DumONT LFC AND D'InCAO F. 2004. Estágios de desenvolvimento gonadal de fêmeas do camarão-barba-ruça (Artemesia longinaris - Decapoda: Penaeidae). Iheringia 94: 389-393.

FERNANDES LP, SILVA AC, JARDIM LP, KEUNECKE KA AND DI BENEDITTO APM. 2011. Growth and recruitment of the Atlantic seabob shrimp, Xiphopenaeus kroyeri (Heller, 1862) (Decapoda, Penaeidae), on the coast of Rio de Janeiro, Southeastern Brazil. Crustaceana 84: 1465-1480.

Fransozo A, COSTA RC, MANTELATTO FLM, PINHEIRO MAA AND SANTOS S. 2002. Composition and abundance of shrimp species (Penaeidea and Caridea) in Fortaleza Bay, Ubatuba, São Paulo, Brazil. In: Moddern Aprroaches of the Study on Crustacea. ESCOBAR-BRIONES E AND ALVAREZ F (Eds), Kluwer Academic/Plenum Publishers, p. 117-123.
FREIRE FAM, LUCHIARI AC AND FRANSOZO V. 2011. Environmental substrate selection and daily habitual activity in Xiphopenaeus kroyeri shrimp (Heller, 1862) (Crustacea: Penaeioidea). Indian J Mar Sci 40: 325-330.

GraÇA-Lopes R, SANTOS EP, SEVERINO-Rodrigues E, BRAGA FMS AND PUZZI A. 2007. Aportes ao conhecimento da biologia e da pesca do camarão-sete-barbas (Xiphopenaeus kroyeri Heller, 1862) no litoral do estado de São Paulo, Brasil. B Inst Pesca 33: 63-84.

Gusmão J, Lazoski C, Monteiro FA And Solé-Cava AM. 2006. Criptic species and population structuring of the Atlantic and Pacific seabob shrimp species, Xiphopenaeus kroyeri and Xiphopenaeus riveti. Mar Biol 149: 491-502.

HAMMER Ø, HARPER DAT AND RYAN PD. 2001. PAST: Paleontological Statistics Software Package for Education and Data Analysis. Palaeo Electronica 4: 1-9.

Heckler GS, Simões SM, Santos APF, Fransozo A AND CostA RC. 2013. Population dynamics of the seabob shrimp Xiphopenaeus kroyeri (Dendrobranchiata, Penaeidae) in south-eastern Brazil. Af J Mar Sci 35: 17-24.

IBAMA. 2007. Estatística da Pesca 2007, Brasil, grandes regiões e unidades de federação. Available at http:// www.ibama.gov.br/documentos-recursos-pesqueiros/ estatistica-pesqueira.

InstituTO DE PESCA. 2013. Estatística pesqueira. Available at http://www.pesca.sp.gov.br/estatistica/index.php

Kumlu M, ERoldogan AT AND AKtas M. 2000. Effects of temperature and salinity on larval growth, survival and development of Penaeus semisulcatus. Aquaculture 188: 167-173.

LÓPEZ AC AND GARCÍA CB. 2001. Postlarvas y juveniles de camarones Farfantepenaeus spp y Xiphopenaeus kroyeri en La Boca de La Barra (Ciénaga Grande de Santa Marta), Caribe Colombiano. Bol Invest Mar Cost 30: 177-198.

MARQUES ASP. 2009. Distribuição espaço-temporal das larvas de camarões (Decapoda) no estuário do Rio Marapanim, Pará, litoral norte do Brasil. Universidade Federal do Pará, Instituto de Ciências Biológicas, 63 p.

PÉQueuX A. 1995. Osmotic regulations in Crustaceans. J Crustac Biol 15: 1-60.

REIGADA ALD, SANT'ANNA BS, ZANGRAND CM AND CostA RC. 2006. Macrocrustacean of non-consolidated sublittoral of the São Vicente Estuarine Bay Complex, São Paulo state, Brazil. Check List 2: 84-88.

Simões SM, Costa RC, Fransozo A And Castilho AL. 2010. Diel variation on the abundance and size of seabob shrimp Xiphopenaeus kroyeri (Crustacea, Penaeoidea) in Ubatuba region, Southeastern Brazil. An Acad Bras Cienc 82: $369-378$

SOKAL RR AND ROHLF FJ. 1995. Biometry: the principles and practices of statistics in biological research, $3^{\text {rd }}$ ed., New York: WH Freeman and Co., 887 p.

ZAR JH. 1996. Biostatistical analysis, $3^{\text {rd }}$ ed., New Jersey: Prentice Hall, 662 p. 